\title{
Analisis Fekunditas dan Diameter Telur Kerang Bambu (Solen lamarckii, Chenu 1843) di Zona Intertidal Desa Api- Api Kecamatan Bandar Laksamana Kabupaten Bengkalis
}

\section{Analysys Fecundity and Egg Diameter of The Bamboo Clam (Solen lamarckii, Chenu 1843) in Intertidal Zone of Api-Api Village Bandar Laksamana District Bengkalis Regency}

\author{
Laila Langsana $^{1 *}$, Syafruddin Nasution $^{2}$ dan Efriyeldi ${ }^{2}$ \\ 'Mahasiswa Fakultas Perikanan dan Kelautan, Universitas Riau \\ ${ }^{2}$ Dosen Fakultas Perikanan dan Kelautan, Universitas Riau \\ *Email: putisulung15@gmail.com
}

\begin{abstract}
Abstrak
Diterima

Kerang bambu (Solen lamarckii) merupakan salah satu tipe moluska dari famili

17 Juni 2020 Solenidae yang dikenal oleh masyarakat sekitar bengkalis dengan sebutan "sepahat". Penelitian ini dilaksanakan di perairan Desa Api-Api, Kabupaten Bengkalis pada bulan Januari 2020. Penelitian ini bertujuan untuk menganalisis jumlah fekunditas pada setiap individu betina kerang bambu dan diameter telur

Disetujui 27 September 2020 pada setiap tingkat kemtangan gonad. Penelitian ini menggunakan metode survey dan penentuan lokasi pengambilan sampel menggunakan metode simpel random sampling. Fakunditas dihitung menggunakan metode volumetrik yang telah dimodifikasi. Hasil menunjukkan fekunditas kerang bambu berkisar antara 290.325-1.902.391 dengan rata-rata 1.105.285 \pm 1.074 .724 butir pada panjang cangkang 50,3-72,8 $\mathrm{mm}$ dan berat 3,25-11,52 gram. Diameter telur kerang bambu berkisar antara $30-110 \mu \mathrm{m}$ dengan rata-rata $52-81,25 \mu \mathrm{m}$ pada panjang cangkang 50,3-72,8 mm. Rata-rata diameter pada setiap tingkat kematangan gonad TKG I adalah 46,7 $\mu \mathrm{m}$, TKG II 65,2 $\mu \mathrm{m}$, TKG III 82,8 $\mu \mathrm{m}$ dan TKG IV $101 \mu \mathrm{m}$.
\end{abstract}

Kata kunci: Fekunditas, diameter telur, Solen lamarckii, Kabupaten Bengkalis.

\begin{abstract}
Bamboo clam (Solen lamarckii) is a type of mollusck of the Solenidae family known as "sepahat" by the people around Bengkalis. This study was conducted at Api-Api village waters, Bengkalis Regency in January 2020. This study aims to investigate the fecundity produced by each female of bamboo clam and egg diameter in each phase of maturity gonad stage. This study used survey method and sampling location determined by simple random sampling. Fecundity was calculated using the modificated volumetric method. The result showed, the fecundity of bamboo clam ranged from 290,325-1,902,391 with an average $1,105,285 \pm 1,074,724$ eggs for 50.3-72.8 mm in shell length. Egg diameter ranged between 30-110 $\mu \mathrm{m}$. Average diameter in each phase of maturity gonad stage, the stage I gonads was $46.7 \mu \mathrm{m}$, stage II $65.2 \mu \mathrm{m}$, stage III $82.8 \mu \mathrm{m}$ and stage IV $101 \mu \mathrm{m}$.
\end{abstract}

Keyword: Fecundity, egg diameter, Solen lamarckii, Bengkalis Regency 


\section{Pendahuluan}

Desa Api-api merupakan salah satu desa yang berada di Kabupaten Bengkalis, yang memiliki sumberdaya alam hayati laut yang melimpah, salah satunya dari jenis bivalvia atau kerang-kerangan. Salah satu jenis kerang yang terdapat di perairan intertidal Desa Api-Api adalah kerang bambu. Kerang bambu Solen lamarckii dikenal oleh masyarakat Bengkalis dengan sebutan Sepahat. Kerang ini berbentuk pipih panjang mirip bambu sebesar jari tangan orang dewasa. Bentuknya unik menyerupai pisau cukur, sehingga disebut juga kerang pisau (razor clam) atau juga jack knife. Solen sp.

Razor clam merupakan kerang yang dikonsumsi dan dijual dengan harga tinggi di pasar internasional (Baron et al., 2004). Kerang bambu di Indonesia diketahui hanya terdapat di beberapa daerah antara lain, Jambi, Madura, Kalimantan Timur, Bengkulu dan juga Riau. Potensi sumberdaya hayati kerang ini menarik untuk diteliti lebih dalam mengingat permintaannya yang semakin meningkat.

Aktivitas penangkapan kerang bambu yang dilakukan oleh nelayan tangkap dan masyarakat sekitar secara terus menerus diduga dapat memberikan tekanan pada menurunnya populasi kerang bambu di alam dan akan mengganggu pertumbuhan populasi tersebut. Penangkapan yang berlangsung setiap saat dan tidak memperhatikan ukuran, diduga dapat menyebabkan rendahnya regenerasi dari spesies tersebut secara alami.

Pengetahuan mengenai fekunditas dan diameter telur merupakan aspek yang penting dalam biologi perikanan, dimana nilai fekunditas dan diameter telur digunakan untuk memprediksi kapan organisme tersebut akan siap melakukan pemijahan. Dengan begitu pada saat nilai fekunditas tinggi penangkapan terhadap kerang ini dapat ditekan agar kelestariannya di perairan terus berlangsung terus menerus (Heriyanto dalam putra et al. (2017)

Terbatasnya informasi dan belum dilakukannya penelitian mengenai aspek biologi dan reproduksi kerang bambu, khususnya mengenai fekunditas dan diameter telur kerang bambu di perairan laut Provinsi Riau, mendorong penulis untuk melakukan penelitian tersebut di Desa Api-Api Kecamatan Bandar Laksamana Kabupaten Bengkalis. Dengan adanya informasi mengenai kerang tersebut, maka manajemen pemanfaatan di masa mendatang dapat dilakukan dengan benar dengan tetap menjaga kelestarian kerang bambu.

\section{Bahan dan Metode}

Penelitian ini dilaksanakan pada bulan Januari 2020 di Zona Intertidal Desa Api-Api Kecamatan Bandar laksamana Kabupaten Bengkalis Provinsi Riau (Gambar 1). Metode yang digunakan dalam penelitian ini adalah metode survei, dimana data yang dikumpulkan adalah berupa sampel kerang bambu serta data kualitas air yang selanjutnya akan disajikan pada tabel dan gambar secara deskriptif.

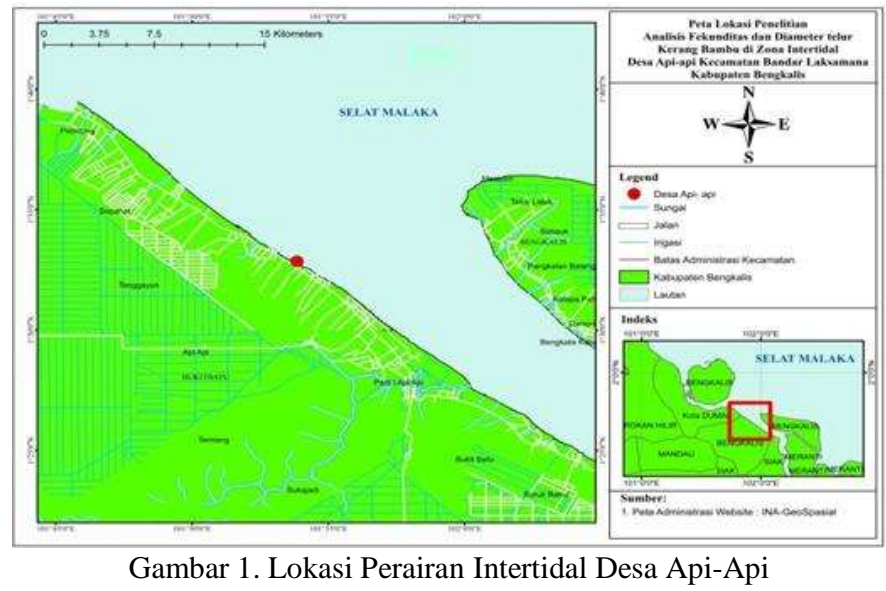

Penentuan titik pengambilan sampel dilakukan secara acak sederhana (simple random sampling) dengan asumsi dapat mewakili ukuran kerang yang terdapat di perairan Desa Api-api. Lokasi penelitian hanya satu stasiun yang terletak di zona intertidal perairan Desa Api-Api. Pengambilan sampel kerang bambu dilakukan pada waktu periode pasang purnama (spring tide). Pengambilan sampel kerang bambu dilakukan satu kali. Sampel diambil ketika air surut menggunakan lidi atau kawat panjang sekitar $30 \mathrm{~cm}$ dan kapur sirih. Sampel diambil sebanyak 40 individu sampel kerang betina. Sampel yang telah terambil kemudian dimasukkan ke dalam kantong plastik yang telah diberi larutan Buffer formalin 10\% hingga seluruh sampel terendam.

Pengambilan sampel kualitas air dilakukan bersamaan dengan pengambilan sampel kerang bambu. Pengambilan sampel kualitas air dilakukaan saat air pasang pada lokasi pengambilan sampel kerang dengan tiga sub zona yaitu upper, middle dan lower. Kualitas air yang diukur yaitu suhu, salinitas, pH,kecerahan, kecepatan arus diukur secara insitu. Sampel air untuk padatan tersuspensi di analisis di laboratorium Kimia Laut. 


\subsection{Indeks Kematangan Gonad}

Analisis indeks kematangan gonad (IKG) dilakukan dengan cara membuka cangkang kerang bambu untuk memisahkan cangkang dan jaringan lunak yang kemudian dilakukan pembedahan dan pemotongan pada jaringan lunak (soft tissue) untuk mengambil gonad berdasarkan ciri-ciri yang terlihat secara morfologi. Kemudian gonad ditimbang menggunakan timbangan analitik dan dilakukan perhitungan Indeks Kematangan Gonad menggunakan rumus (Effendie, 2002) sebagai berikut:

Keterangan:

\section{IKG = BG/BT x $100 \%$}

$$
\begin{aligned}
& \text { IKG }: \text { Indeks Kematangan Gonad (\%) } \\
& \text { BG : Berat Gonad (gram) } \\
& \text { BT : Berat Tubuh (gram) }
\end{aligned}
$$

\subsection{Tingkat Kematangan Gonad (TKG)}

Tingkat kematangan gonad (TKG) menunjukkan suatu tingkatan kematangan seksual organisme. Penentuan TKG kerang bambu dilakukan berdasarkan pengamatan ukuran gonad dan ukuran diameter telur berdasarkan kriteria yang dikemukan oleh Hmida et al. (2010) (Tabel 1).

Tabel 1. Kriteria Penentuan Tingkat Kematangan Gonad

\begin{tabular}{ll}
\multicolumn{1}{c}{ Tingkat Kematangan Gonad (TKG) } & \multicolumn{1}{c}{ Ciri-ciri } \\
\hline Fase 0 atau Fase istirahat (resting) & $\begin{array}{l}\text { Pada tahap ini telur memiliki ciri-ciri ukuran gonad sangat kecil, sehingga } \\
\text { belum bisa dibedakan antara gonad jantan dan betina. }\end{array}$ \\
Fase I & $\begin{array}{l}\text { Pada fase ini gonad tumbuh dengan ukuran lebih besar dari stage 0. Mulai } \\
\text { terlihat oosit previtelogenik. }\end{array}$ \\
Fase II & $\begin{array}{l}\text { Pada tahap ini diameter telur semakin membesar dan oosit telah memasuki } \\
\text { tahap vitelogenik (proses pembentukan kuning telur). } \\
\text { Pada fase ini ditandai dengan diameter telur yang besar dan berbentuk } \\
\text { polygonal serta terdapat oosit vitelogenik. Terlihat beberapa oosit mengalami } \\
\text { artresia. }\end{array}$ \\
Fase III & $\begin{array}{l}\text { Pada fase ini oosit mengalami sitolisis (sitoplasma hilang) sehingga diameter } \\
\text { menjadi sangat besar. }\end{array}$ \\
\hline $\begin{array}{l}\text { Fase IV atau Fase Setelah Pemijahan } \\
\text { (Exhaustion) }\end{array}$ &
\end{tabular}

\subsection{Fekunditas dan Diameter Telur}

Analisis perhitungan fekunditas kerang bambu dilakukan dengan cara membuka cangkang kerang bambu untuk memisahkan cangkang dan jaringan lunak yang kemudian dilakukan pembedahan dan pemotongan pada jaringan lunak (soft tissue) untuk mengambil gonad berdasarkan ciri-ciri yang terlihat secara morfologi. Lalu Setelah dipastikan bahwa gonad tersebut betina, maka gonad dimasukkan ke dalam botol sampel yang berisi larutan buffer formalin $10 \%$ hingga gonad terendam.

Setelah didapatkan 40 sampel gonad betina kerang bambu kemudian dilakukan pengukuran terhadap diameter telur. Pengukuran diameter dilakukan terhadap 20 butir sampel telur per individu kerang bambu. Menggunakan mikroskop binokuler micrometer Olympus CX21, dengan perbesaran (10x10) dan tingkat ketelitian $0.01 \mu \mathrm{m}$. Sampel telur kerang bambu diambil sedikit pada bagian ujung atas, tengah dan ujung bawah gonad.

Gonad kerang bambu yang telah diamati diameter telurnya kemudian dipisahkan dari seluruh jaringan tubuh (soft tissue) dan saluran pencernaan. Gonad kemudian ditimbang menggunakan timbangan analitik, guna mendapatkan berat total gonad. lalu volume total gonad diukur menggunakan spuit suntik. Setelah didapatkan diameter telur, berat total gonal dan volume total gonad. dilakukan perhitungan terhadap fekunditas kerang bambu. Perhitungan fekunditas dilakukan dengan metode volumetric yang telah dimodifikasi oleh Efriyeldi $e t$ al., (2012). Jumlah telur dinyatakan sebagai berikut :

\section{$\mathbf{F}=\mathbf{V} / \mathbf{V T}$}

Keterangan :

$\mathrm{F}=$ fekunditas (butir telur)

$\mathrm{V}=$ volume total telur gonad $\left(\mathrm{ml}^{3}\right)$

$\mathrm{VT}=$ volume satu butir telur $\left(\mathrm{ml}^{3}\right)$

\subsection{Padatan Tersuspensi (TSS)}

Pengambilan sampel air dilakukan untuk mengetahui jumlah padatan tersuspensi atau TSS (Total Suspended Solid). Sampel air diambil sebanyak 1 liter pada dasar perairan menggunakan botol sampel pada masing-masing subzona dengan 3 kali pengulangan lalu dicampur menjadi 1. Analisis padatan tersuspensi dilakukan dengan metode gravimetri menurut SNI 06-6989-3-2004 sebagai berikut; kertas saring dipanaskan di dalam oven pada suhu $\pm 105^{\circ} \mathrm{C}$ selama 15 menit. Kemudian didinginkan dalam desikator selama 5 menit dan ditimbang segera dengan neraca analitik hingga didapatkan berat konstan. Kemudian sampel dikocok hingga 
homogen dan diambil sebanyak $100 \mathrm{ml}$ dan dilakukan penyaringan menggunakan alat penyaring dan kertas saring. Kemudian kertas saring diambil dengan hati-hati dan diletakkan di atas cawan untuk dipanaskan di dalam oven dengan suhu $105^{\circ} \mathrm{C}$ selama 2 jam. Selanjutnya didinginkan dalam desikator dan ditimbang segera dengan neraca analitik hingga diperoleh berat konstan. Untuk mengetahui jumlah total padatan tersuspensi dilakukan perhitungan dengan rumus:

Keterangan:

$$
\text { TSS }=((\mathbf{A}-\mathrm{B}) \times 1000) / \mathrm{V}
$$

A $=$ Berat filter dan residu sesudah pemanasan $(\mathrm{g})$

$\mathrm{B}=$ Berat kertas saring kosong $(\mathrm{g})$

$\mathrm{V}=$ Volume sampel (1)

\section{Hasil dan Pembahasan}

\subsection{Deskripsi Lokasi Penelitian}

Desa Api-Api yang merupakan lokasi penelitian yang masuk kedalam wilayah Kecamatan Bandar Laksmana Kabupaten Bengkalis Provinsi Riau. Secara geografis Kecamatan Bandar Laksmana bersebelahan dengan Kecamatan Bukit Batu (Gambar 1). Luas wilayah Kecamatan Bandar Laksmana adalah 640 km². Kecamatan ini terdiri dari 7 desa dengan desa terluas yaitu Tenggayun seluas $145 \mathrm{~km}^{2}$, dan yang terkecil yaitu Desa Tanjung Leban dengan luas 20,4 $\mathrm{km}^{2}$ atau sebesar 8,16\% dari luas keseluruhan Kecamatan Bandar Laksmana (BPS Kabupaten Bengkalis, 2017).

Perairan Desa Api-Api merupakan perairan yang memiliki potensi sumber daya alam yang melimpah baik sektor perikanan, perkebunan hingga minyak bumi. Pantai yang terdapat di Desa Api-Api mempunyai bentuk landai yang berhadapan langsung dengan perairan Selat Malaka. Pantai ini umumnya ditumbuhi oleh vegetasi mangrove yang dikelola oleh desa. Hutan mangrove ini membentang sepanjang pantai hingga jarak yang cukup jauh. Substrat di pantai ini sendiri adalah jenis substrat pasir berlumpur yang umumnya dijumpai pada daerah wilayah Provinsi Riau.

\subsection{Indeks Kematangan Gonad (IKG)}

Indeks Kematangan Gonad (IKG) merupakan tanda untuk membedakan kematangan gonad berdasarkan berat gonad dan secara alami berhubungan dengan ukuran dan berat tubuh (Octavina, 2014). Indeks kematangan gonad kerang bambu yang diperoleh selama penelitian berkisar antara 1,2 - 10,6\%. Berdasarkan pengamatan ditemukan indeks kematangan gonad yang berbeda pada tiap pengelompokan IKG (Gambar 2). Terlihat bahwa kerang bambu paling banyak terdapat pada IKG $<4 \%$ dan yang paling sedikit pada IKG $>8 \%$. Hal ini diduga karena fase pemijahan kerang bambu.

Nilai indeks kematangan gonad mengalami perubahan seiring perubahan Tingkat Kematangan Gonad (TKG) dan mencapai puncak sesaat akan memijah, sehingga Indeks Kematangan Gonad (IKG) dapat digunakan untuk mengetahui musim pemijahan. Hal ini sesuai dengan pernyataan Efriyeldi et al. (2012), nilai indeks kematangan gonad dari setiap bulan akan berbeda-beda, sesuai dengan besarnya fekunditas serta besarnya diameter telur dari suatu kerang.

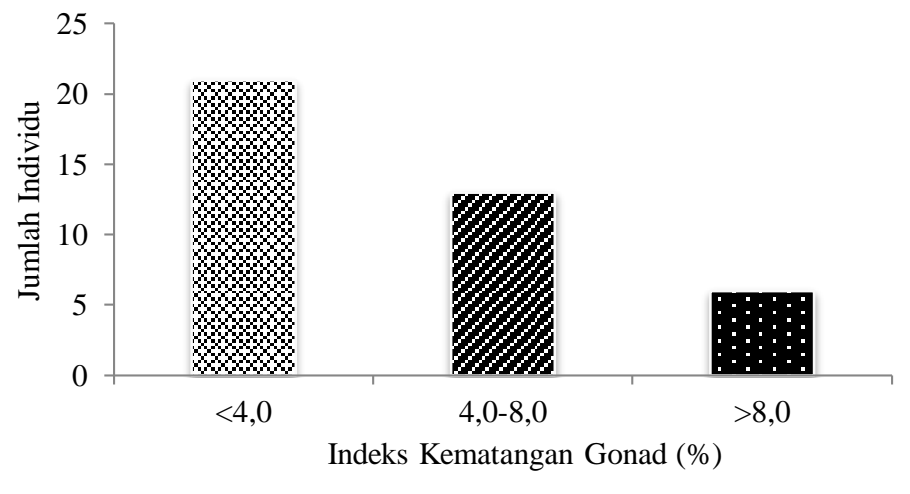

Gambar 2. Indeks Kematangan Gonad Kerang Bambu (S. lamarckii)

\subsection{Fekunditas Kerang Bambu}

Fekunditas atau jumlah telur yang dihasilkan oleh kerang bambu sangat besar. Fekunditas kerang bambu pada perairan intertidal Desa Api api berkisar antara 290.325-1.902.391 butir telur. Rata-rata fekunditas 1.105.285 \pm 1.074 .724 butir telur per individu. Jumlah ini relatif sama dengan fekunditas yang didapatkan oleh Hoang dan Tuyen (2016) pada jenis Solen tachi di Laguna Thuy Trieu, Vietnam adalah 1.048.893 \pm 608.964 telur per individu. Besarnya jumlah telur yang diproduksi oleh kerang sangat penting, karena kerang merupakan 
biota dengan fertilisasi eksernal. Hasil dari fertilisasi eksternal berkurang karena adanya predasi, polusi, dan faktor lingkungan lainnya seperti suhu, salinitas, kecerahan dan kecepatan arus.

Berdasarkan penelitian yang telah dilakukan kecerahan di perairan pantai Desa Api-Api adalah $13-45 \mathrm{~cm}$. Nilai kecerahan ini dipengaruhi oleh bentuk pantai Desa Api-Api yang landai dan perairannya dangkal sehingga penetrasi cahaya matahari menembus hingga ke dasar perairan. Rata-rata kecepatan arus di perairan pantai Desa Api-Api adalah 0,09 m/detik. Kecepatan arus ini tergolong sangat lambat. Menurut Wijaya (2009) bahwa arus dibagi menjadi 5 kategori yaitu arus sangat cepat $(>1 \mathrm{~m} / \mathrm{det})$, cepat $(0,5-1 \mathrm{~m} / \mathrm{det})$, sedang $(0,25-0,5 \mathrm{~m} / \mathrm{det})$, lambat $(0,10 \mathrm{~m} / \mathrm{det})$ dan sangat lambat $(<0,10 \mathrm{~m} / \mathrm{det})$.

Padatan tersuspensi yang terdapat di perairan pantai Desa Api-Api berkisar 132-421 mg/l. Nilai ini sangat tinggi jauh di atas standar baku mutu air laut menurut Keputusan Menteri Lingkungan Hidup No. 51 Tahun 2004 untuk biota laut yaitu $<80 \mathrm{mg} / \mathrm{l}$. Nilai TSS yang terlalu tinggi akan memberikan dampak buruk terhadap kualitas air karena akan mengurangi penetrasi cahaya matahari ke dalam badan air dan menyebabkan nilai kekeruhan yang tinggi sehingga dapat menggangu metabolisme biota.

Suhu menjadi salah satu faktor penting dalam tingginya jumlah fekunditas kerang. Berdasarkan hasil pengamatan rata-rata suhu pada perairan Desa Api-Api adalah $30^{\circ} \mathrm{C}$. Nilai tersebut merupakan suhu yang optimal untuk pertumbuhan serta perkembangan gonad kerang bambu sehingga jumlah telur yang di produksi meningkat dan nilai fekunditas tinggi. Hal ini sesuai dengan pernyataan Sitorus dalam Zulkifli (2020) yang menyatakan bahwa suhu yang optimal untuk pertumbuhan bivalva berkisar antara $25-31^{\circ} \mathrm{C}$. Sedangkan kisaran suhu optimum untuk perkembangan gonad kerang menurut Shumway (2006) berkisar antara $20-30^{\circ} \mathrm{C}$.

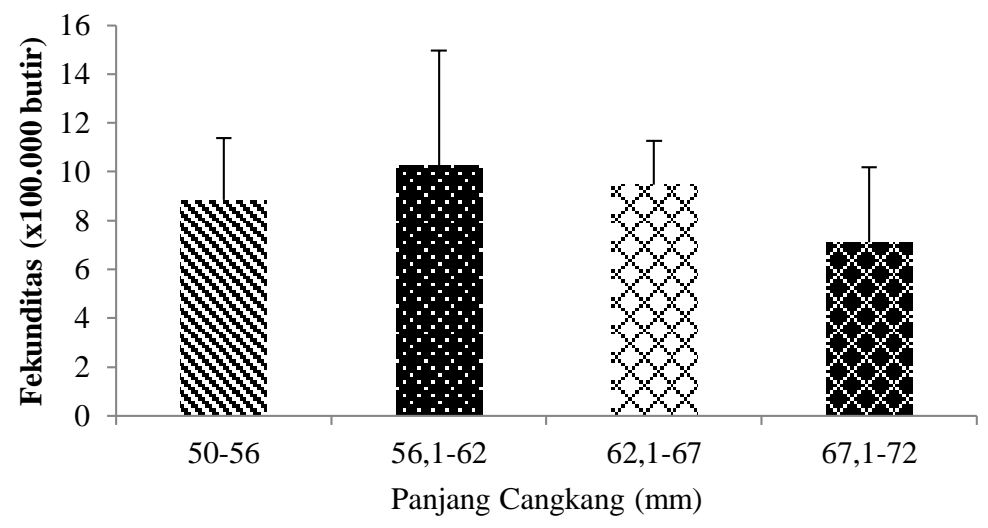

Gambar 3. Rata-rata Fekunditas kerang bambu (S. lamarckii)

Beberapa parameter lingkungan lain yang mempengaruhi jumlah fekunditas kerang bambu adalah salinitas dan $\mathrm{pH}$. Berdasarkan penelitian yang telah dilakukan salinitas yang terdapat di zona intertidal perairan Desa Api-Api berkisar antara 27-30 ppt. Nilai salinitas yang diperoleh masih dalam kondisi baik untuk pertumbuhan kerang. Hal ini sesuai dengan pernyataan Trisyani (2018) yang menyatakan bahwa rata-rata salinitas sebesar 2036 ppt merupakan nilai salinitas yang sesuai dengan habitat kerang bambu. Nilai kisaran salinitas tersebut kerang dapat bertahan hidup. Sebagian besar bivalvia dapat hidup dengan baik pada kisaran salinitas 5-35 ppt. Nilai pH di zona intertidal perairan Desa Api-Api yaitu 7. Nilai ini masih tergolong baik untuk bagi kehidupan kerang. Hal ini sesuai dengan pernyataan Natan et al. (2008) yang menyatakan nilai pH 6,5-7,5 termasuk baik untuk perkembangan moluska sebab $\mathrm{pH}$ yang kurang dari 5 dan lebih besar dari 9 menciptakan kondisi yang tidak menguntungkan bagi makrozoobenthos.

Kerang bambu merupakan kerang yang memiliki ruang internal cangkang yang luas. Sehingga ketika kerang berada pada tahap matang gonad (mature) cangkang kerang hampir semuanya dipenuhi oleh gonad mulai dari ujung kaki sampai batas akhir saluran pencernaan kerang. Rahmawati et al. (2017) mengatakan bahwa fekunditas tinggi pada bivalvia secara umum merupakan hal yang wajar mengingat ruang internal cangkang kerang ini cukup luas untuk pertumbuhan gonad, sehingga dapat memproduksi telur lebih banyak. Adapun temuan rendahnya jumlah fekunditas dalam penelitian ini dimungkinkan sebagai akibat dari telah dikeluarkannya telur sebagian oleh kerang bambu pengangkapan kerang secara berlebihan oleh masyarakat sekitar serta faktor lingkungan lainnya.

Pada penelitian yang telah dilakukan kerang dengan panjang cangkang 56,10-62 mm memiliki rata-rata fekunditas 1.024.18 \pm 437.181 butir. Kerang dengan panjang 67,1-72 memiliki rata-rata fekunditas 712.160 \pm 306.274 butir (Gambar 3). Hal ini menunjukkan bahwa pada kerang dengan ukuran panjang yang lebih besar mempunyai nilai fekunditas yang lebih kecil dibandingkan dengan ukuran cangkang yang lebih pendek. Ini diduga bahwa kerang dengan ukuran lebih besar tersebut merupakan kerang dewasa yang telah melakukan pemijahan berkali-kali. Kerang tersebut berada pada fase exhausted/full spent fhase dimana pemijahan telah selesai dilakukan dan masih terdapat sisa telur didalam gonad kerang bambu. Sehingga fekunditas yang didapat nilainya tidak besar dan lebih kecil dibanding dengan ukuran kerang yang lebih pendek. Rahmawati et al. 
(2017) menyatakan bahwa kondisi ini diduga kerang dewasa tersebut telah melakukan pemijahan berkali-kali sehingga fekunditas yang dimilikinya menjadi lebih berkurang (rendah).

Hoang dan Tuyen, (2016) menyebutkan bahwa kerang Solen taichi famili Solenidae merupakan kerang yang memijah sepanjang tahun dengan musim kawin utama pada bulan Desember hingga Maret. Sementara Efriyeldi et al. (2012) menyatakan bahwa kerang sepetang merupakan kerang yang memijah secara bertahap dengan mengeluarkan sebagian sel telur dan sel spermanya. Hal ini sesuai dengan pernyataan Widyastuti (2011) bahwa kerang merupakan biota yang tidak memijah sekaligus, tetapi secara bertahap dalam periode yang panjang, bahkan hampir setiap bulan sepanjang tahun masih ditemukan kerang yang memijah.

\subsection{Diameter Telur Kerang Bambu (S. lamarckii)}

Diameter telur kerang bambu yang diperoleh selama penelitian berkisar antara 30-110 $\mu \mathrm{m}$. Dengan rata-rata ukuran diameter telur per individu kerang antara 52-81,25 $\mu \mathrm{m}$. Diameter telur yang didapat di perairan Desa Api-Api lebih besar dari pada diameter telur Solen sp. yang ditemukan oleh Ningsih (2016) pada perairan pantai pemekasan Madura yaitu berkisar antara 0,7-32,4 $\mu \mathrm{m}$. Hmida et al. (2010) menyatakan Solen margiatus memiliki ukuran diameter berkisar antara 0-40 $\mu \mathrm{m}$ pada setiap tingkat kematangan gonad. Perbedaan ukuran diameter telur diduga disebabkan oleh faktor lingkungan tempat kerang hidup, nutrisi, morfologi dan perbedaan spesies kerang.

Hasil analisis diameter telur kerang bambu terhadap tingkat kematangan gonad (TKG) didapat diameter dengan rentang ukuran 30-50 $\mu$ m merupakan TKG I, kerang bambu dengan diameter 51-70 $\mu$ m merupakan TKG II. Diameter 71-90 $\mu$ merupakan TKG III dan $>91 \mu \mathrm{m}$ merupakan TKG IV (exhaustion phase). Dari 40 sampel kerang bambu yang dianalisis selama penelitian. 28 individu merupakan TKG II dan 12 individu berada pada TKG III (Gambar 4).

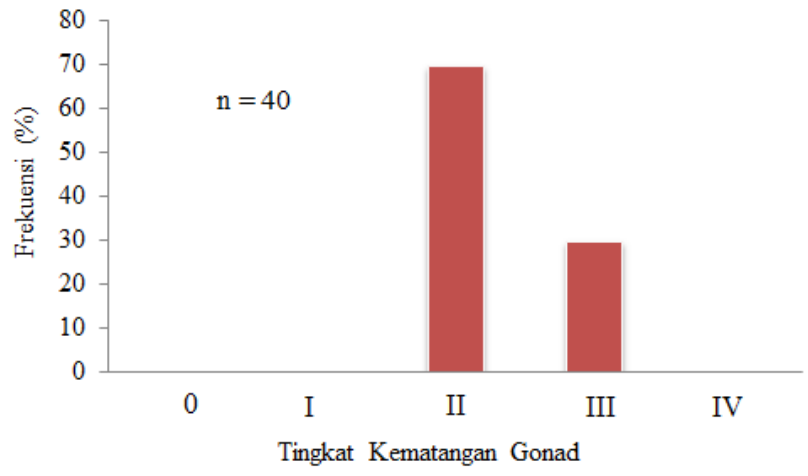

Gambar 4. Jumlah Individu (\%) pada Tingkat Kematangan Gonad Tertentu

Pada TKG I, mengandung oosit previtelogenik yang mempunyai kisaran ukuran 30-50 $\mu \mathrm{m}$. Pada TKG II yang mengandung oosit previtelogenik dan oosit vitelogenik menunjukkan kisaran ukuran oosit 51-70 $\mu \mathrm{m}$. Pada TKG III yang mengandung oosit vitelogenik saja menunjukkan kisaran ukuran oosit 71-90 $\mu$ m. Sementara itu, oosit yang telah mengalami sitolisis pada TKG IV menunjukkan kisaran $>91 \mu \mathrm{m}$. Sebagai perbandingan pengelompokan TKG berdasarkan ukuran oosit juga dilakukan oleh Hmida et al. (2010) pada S. marginatus dengan hasil sebagai berikut : oosit pada TKG I berukuran > $15 \mu \mathrm{m}$, sedangkan pada TKG II diameter oosit berkisar antara 15-25 $\mu \mathrm{m}$ dan TKG III berukuran 25-40 $\mu \mathrm{m}$. Sementara oosit pada TKG IV mulai mengalami penyusutan ukuran dibandingkan TKG III dengan bentuk iregular, dan sebagian menunjukkan kerusakan struktur membran. Gribben dalam Ningsih (2016) menyatakan bahwa beberapa studi yang menggunakan studi kuantitatif menunjukkan periode matang dan pemijahan cenderung pada ukuran oosit yang maksimum.

Pada penelitian ini ditemukan kerang bambu dengan TKG II dan III berdasarkan pengelompokan rata-rata diameternya. Sebanyak 28 individu pada TKG II dan 12 individu pada TKG III (Gambar 4). Tidak ditemukan individu dengan TKG 0 (istirahat), I (gametogenesis awal) dan TKG IV (exhaution). Kondisi ini diduga terkait dengan waktu pengambilan sampel kerang bambu. Pengambilan sampel dilakukan pada bulan Januari yang merupakan musim pemijahan kerang bambu. Hoang dan Tuyen (2016) menyebutkan bahwa kerang bambu betina (S. tachii) secara seksual akan mencapai puncak kematangan gonad pada bulan Desember. Siklus ini dimulai dari awal agustus hingga mencapai puncak pada bulan Desember dan secara bertahap menurun hingga Maret.

Kerang bambu (S. lamarckii) merupakan kerang dengan durasi pemijahan yang panjang dan dapat memijah sepanjang tahun. Spesies kerang ini memiliki musim kawin utama pada bulan-bulan tertentu. Jenis kerang bambu di perairan tropis seperti $S$. trictus, $S$. thailandicus, $S$. corneus dan $S$. regularis memiliki musim kawin utama yaitu pada bulan Desember-April dan Juni-Oktober (Hoang dan Tuyen, 2016). 


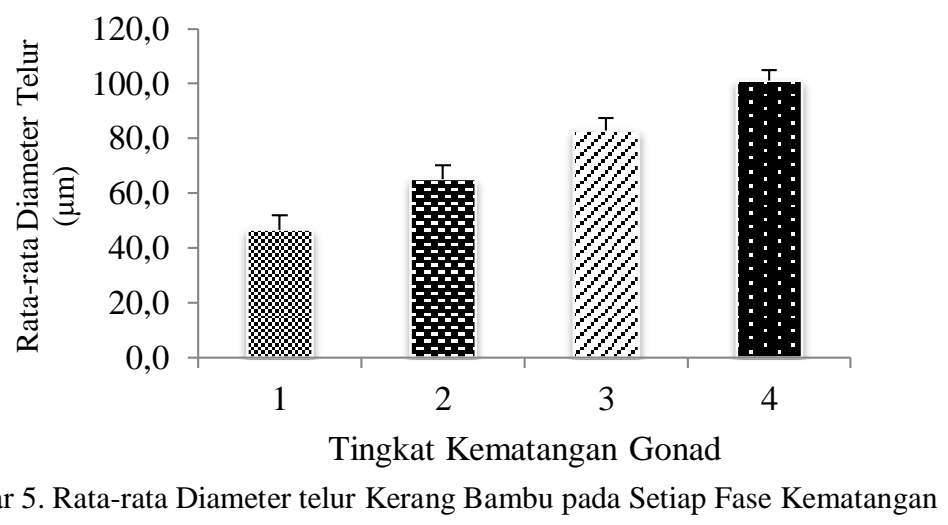

Pada Gambar 5, TKG III dengan rata-rata diameter telur $82,2 \mu \mathrm{m}$ merupakan fase puncak kematangan gonad atau fase pemijahan. Fase IV dengan rata-rata diameter tertinggi yaitu $101 \mu \mathrm{m}$ merupakan fase exhaustion/full spent phase dimana kerang telah selesai melakukan pemijahan dan tersisa beberapa gonad di bagian dalam, oosit yang tersisa mengalami sitolisis (sitoplasma hilang) sehingga diameter menjadi sangat besar. Terlihat bahwa semakin tinggi fase perkembangan gonad atau tingkat kematangan gonad kerang bambu, maka diameter telurnya semakin besar. Raharjo et al. (2011) mengatakan bahwa semakin tinggi tingkat kematangan gonad kerang maka garis tengah telur yang ada dalam ovarium semakin besar.

Variasi diameter telur yang ditemukan pada penelitian ini juga memperlihatkan bahwa telur kerang tidak matang secara bersamaan. Pada individu kerang tidak ditemui telur dengan ukuran yang sama pada setiap pengamatan. Telur-telur yang telah matang dipijahkan secara bertahap, sehingga dapat dikatakan bahwa kerang bambu memijah secara persial (sebagian).

\section{Kesimpulan} bahwa:

Berdasarkan hasil penelitian yang telah dilakukan di zona intertidal Desa Api-Api, maka dapat disimpulkan

1. Fekunditas kerang bambu berkisar antara 290.325-1.902.391 butir telur dengan rata-rata fekunditas 1.105.285 \pm 1.074 .724 butir telur per individu pada panjang cangkang 50,3-72,8 $\mathrm{mm}$ dan berat 3,25-11,52 gram.

2. Diameter telur kerang bambu berkisar antara 30-110 $\mu \mathrm{m}$ dengan rata-rata diameter pada setiap individu 52$81,25 \mu \mathrm{m}$. Rata-rata diameter kerang bambu pada setiap fase/tingkat kematangan gonad TKG I adalah 46,7 $\mu \mathrm{m}$, TKG II 65,2 $\mu \mathrm{m}$, TKG III 82,8 $\mu \mathrm{m}$ dan TKG IV $101 \mu \mathrm{m}$.

\section{Saran}

Pada penelitian ini hanya mengkaji tentang fekunditas dan diameter telur kerang bambu pada bulan Januari. Diharapkan untuk penelitian selanjutnya agar dapat melakukan penelitian mengenai fekunditas dan diameter kerang bambu pada bulan-bulan lainnya.

\section{Referensi}

[BPS] Badan Pusat Statistik Kabupaten Bengkalis. 2017. BPS Kabupaten Bengkalis.

Baron, P.J., L.E. Real, N.F. Ciocco and M.E. Re. 2004. Morphometry, Growth and Reproduction of an Atlantic Population of the Razor Clam Ensis macha (Molina, 1782). Scienticia Marina, 68 (2): 211-217

Effendie, M.I. 2002. Biologi Perikanan Bagian I. Studi Natural Histori. Institut Pertanian Bogor.

Efriyeldi., D.G. Bengen, R. Affandi dan T. Prartono. 2012. Perkembangan Gonad dan Musim Pemijahan Kerang Sepetang (Pharella acutidens) di Ekosistem Mangrove Dumai, Riau. Maspari Journal, 4(2): 137-147.

Gribben, P.E. 2005. Gametogenic Development and Spawning of the Razor Clam, Zenatia acinades in northeastern New Zealand. New Zealand Journal of Marine and Freshwater Study, 39: 1287-1296.

Hmida, L., N. Ayache, Z, Haouas, and M.S. Romadhen. 2010. Oocyte Cohort Analysis: Criteria for an Evaluation Of The Reproductive Cycle in Solen marginatus (Penna' Nt, 1777), (Bivalvia: Solenacea). Southern Tunisia. Journal of Shellfish Study. 29(1):129-134.

Hoang, D.H and H.T. Tuyen, 2016. Reproductive Biology og Razor Clam Solen tachii Cosel 2002 at Thuy Trieu Lagoon Khan Hoa. Tạp chi Khoa họ và Công nghệ Biển. 16(2): 198-204.

Ningsih, S.T.W. 2016. Studi Tingkat Kematangan Gonad Lorjuk (Solen sp.) di Pantai Pamekasan Madura. Skripsi. Jurusan Biologi. Institut Teknologi Sepuluh Nopember. Surabaya. 
Keputusan Menteri Lingkungan Hidup No. 51 tahun 2004. Tentang Baku Mutu Air Laut. Kantor Menteri Negara Lingkungan Hidup, Jakarta.

Rahmawati, L., Bahtiar, dan Haslianti. 2017. Aspek Biologi Reproduksi Kerang Pasir (Modiolus modulaides) di Perairan Bungkutoko Kota Kendari Provinsi Sulawesi Tenggara. Jurnal Manajemen Sumber Daya Perairan, 2(4): 243-250.

Putra, R.M., A. Hindriyani, D. Efrizon, D. Yoswaty, Efawati, dan Windarti. 2017. Buku Ajar Biologi Perikanan. Pekanbaru: UR Press.

Trisyani, N., B. Irawan dan N. Rosana. (2007). Faktor Lingkungan Yang Mempengaruhi Kepadatan Lorjuk (Solen vaginalis) Di Perairan Pantai Timur Surabaya. Prosiding Seminar Nasional Moluska dalam Penelitian, Konservasi dan Ekonomi. Universitas Diponegoro. Semarang. 168-174.

Zulkifli, M., S. Nasution, dan Efriyeldi. 2020. Relationship of the Content of Organic Materials in Sediment with Density of Solen lamarckii in Intertidal Zone of Api-Api Village, Bengkalis. Journal of Coastal and Ocean Sciences, 1(1): 7482 